\title{
女性スポーツ選手における食事記録法による エネルギー摂取量の評侕愦差に関連する要因
}

\author{
吉田明日美*1, *2, 商田 和子*2, 別所 京子*2,*3，田口 素子*4, \\ 辰田和佳子*5, 戸谷 誠之*6, 樋口＼cjkstart満*4 \\ *1早稲田大学大学院スポーツ科学研究科 $* 2($ 独) 国立健康・栄養研究所栄養教育研究部 \\ *3聖德大学人間栄養学部 *4早稲田大学スポーツ科学学術院 *5国立スポーツ科学センター \\ *6昭和女子大学大学院生活機構研究科
}

\begin{abstract}
【目的】女性スポーツ選手を対象に, 二重標識水（DLW）法で測定した総エネルギ一消費量（TEE）と, 食事記録法より求めた総エネ ルギー掑取量（TEI）から算出した TEI 評価誤差に対する種目や身体組成，食事䀧取状況の関連を明らかにすることを目的とした。 【方法】大学女性選手38名（陸上中長距離 9 名, 水泳10名, 新体操7名, ラクロス12名) を対象とした。体重補正済み TEE (CTEE) は DLW 法で求めた TEE と調查期間中の体重変動から算出し、TEI は同期間に実施した食事記録法による食事調査から計算した。

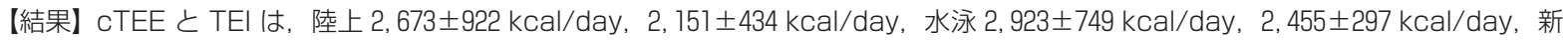

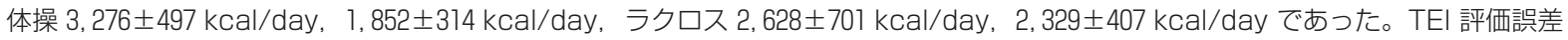
は，陸上- $13.6 \pm 24.1 \% ，$ 水泳一 $13.3 \pm 14.3 \% ，$ 新体操 $-42.0 \pm 15.3 \% ，$ ラクロス $-2.8 \pm 38.3 \%$ ありり，種目間の比較では新体操が 有意に過小評価していたが, 身体組成や食事摄取状況には競技特性はみられず, 同一種目間の個人差が大きかった。評価誤差の大小で

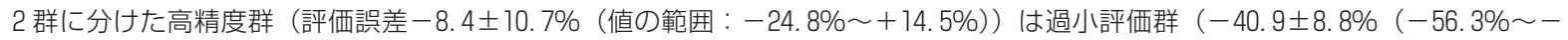
28. 7\%)）より TEE, 脂質エネルギー比率が有意に低值であり, 菓子類拱取量, 食事回数, 炭水化物エネルギー比率が有意に高值であっ た。TEEが小さいことは高精度群への分類に独立して関連していた。

【結論】女性選手の評価誤差には，TEE が独立して関連し，種目や食品群別摃取量，エネルギー比率，食事回数が関連する可能性が示 された。今後は, 対象種目の再㛟討や対象者数の増加とともに, 心理的, 社会的要因を含めた, 評価誤差に関連する要因の㛟討が必要 と考えた。
\end{abstract}

栄養学䧱誌, Vol.70 No.5 305-315 (2012)

キーワード：女性スポーツ選手，二重標識水法，食事記録法，過小評価

\section{I. 緒言}

スポーツ選手がパフォーマンスの向上を目的としてト レーニングを継続的に行うとき, 食事はより高いトレー ニング効果を得るために大切な要素である。スポーツ選 手の食事管理を行うためには, トレーニングの目的・内 容などに加えて，日常的な食事の摂取量を正確に把握す る必要がある。

食事の摂取量の把握は食事調査によって行われること が多いが，食事調查には評価誤差が生じることが知られ ている。総エネルギー消費量 (Total Energy Expenditure: TEE）と総エネルギー摂取量（Total Energy Intake: TEI） は, 体重変化のない状態では等しくなると仮定できる1) ことから, エネルギーに着目して食事調査の評価誤差を 検討することが可能である。Poslusna ら ${ }^{2)}$ は, 二重標識 水 (Doubly Labeled Water: DLW) 法 ${ }^{3)}$ により測定した TEE を用いて，24時間思い出し法と食事記録法のいずれ もが TEI を過小に評価していたと報告している。日本人
を対象に DLW 法を用いて TEI の評価誤差を検討した研 究では，食事歴法と食事記録法がいずれも TEI を過小に 評価すると報告されている ${ }^{4,5)}$ 。スポーツ選手においても TEI の過小評価が指摘されているが，評価誤差の範囲は 0 ～ $43 \%$ と大きい ${ }^{6)}$ 。日本人スポーツ選手を対象とした 研究では, TEI の評価誤差は男性プロサッカー選手でー $12 \%^{7)}$, 女性シンクロナイズドスイミング選手で- $22 \%{ }^{8)}$ と報告されている。

一般人を対象に, TEI 評価誤差の大きさに影響する要 因を検討している研究は多数存在する。このうち, 性 $^{5,9)}$, 年齢 5,10$)$, BMI (Body Mass Index $)^{5,9,11)}$, 主要 栄養素の摂取量 $\left.{ }^{9}, 12,13\right)$, 食品群別摂取量 ${ }^{13,14)}$, 食事回 数 ${ }^{4)}$, 身体活動レベル (Physical Activity Level: PAL $)^{5)}$, $\mathrm{TEE}^{15,16)}$ は，スポーツ選手においても評価誤差に影響す る可能性がある。スポーツ選手では, 競技ごとに有利と なる体格が異なっている。また，持久的なトレーニング, 筋力トレーニング，技術的なトレーニングなど実施して いるトレーニング内容の比率も異なる。これらの有利と

連絡先：高田和子 $=162-8636$ 東京都新宿区戸山1-23-1 (独) 国立健康 - 栄養研究所栄養教育研究部

電話 03-3203-5418 E-mail kazu@nih.go.jp 
なる体格やトレーニング内容の違いが, 必要とされる栄 養素の摂取量や実際の食事内容, 身体活動量にも影響す ると考えられる。例えば, たんぱく質の推奨量は, 主に 持久的なトレーニングを行う選手では $1.2 \sim 1.4 \mathrm{~g} / \mathrm{kg} / \mathrm{day}$ であるのに対し, 主に筋力トレーニングを行う選手では $1.6 \sim 1.7 \mathrm{~g} / \mathrm{kg} / \mathrm{day}$ とされている ${ }^{17)}$ 。そのため, 一般人 でみられた主要栄養素の摂取量, 食品群別摂取量, 食事 回数, PAL などの TEI 評価誤差への影響が, スポーツ選 手では一般人と異なる, あるいは競技種目ごとにそれら の TEI 評価䛊差への影響が異なる可能性がある。しかし， これまでのスポーツ選手の TEI 評価䛊差に関する研 究7,8,18,19) では, いずれも影響する要因の検討までは行 われていない。また, 複数の競技種目の評価誤差を 1 つ の研究で比較した研究はみられない。

そこで, 本研究においては, 有利となる体格や主要な トレーニング内容が大きく異なることを予測して以下の 4 種目を対象とした。1つに, 体重が軽いことが有利と なり, 持久的なトレーニングを主とする種目として陸上 長距離選手を対象とした。同様に体格が小さくプロポー ションが重視され，技術的なトレーニングを主とする審 美系の種目として新体操選手を対象とした。一方で, 必 ずしも体格が小さいことが有利とならない競技として, 体脂肪量の維持が浮力の獲得や体温低下の防止に有利で ある水泳選手を取り上げた。さらに, 選手同士の接触が あり除脂肪量（Fat Free Mass: FFM）が傷害等を防ぐた めに必要となる混合系の種目として, ラクロスを取り上 げた。一般人における先行研究 ${ }^{11)}$ の結果を考慮すると, 体重の管理が重要視される陸上長距離や新体操では, 体 重管理の意識から過小評価が大きくなる可能性がある。 また，一般人では BMI が高いほど，過小評価が大きく なっているが, 有利となる体格が種目によって異なるス ポーツ選手では, BMI の大小の影響は種目によって異な るかもしれない。持久的なトレーニングの多い陸上選手 や体脂肪量の維持が重要な水泳選手では, 一般人におい て指摘されるような炭水化物の摂取比率の多い者で過小 評価される13) といった傾向は少ない可能性もある。本研 究では, これらの対象者において通常トレーニング期に, DLW 法で測定した TEE を基準として食事記録法より求 めた TEI の評価䛊差を種目間で比較することと, その評 価誤差に種目や身体組成, 食事回数などの食事摂取状況 の違いがどのように関連するかを明らかにすることを目 的とした。

\section{II. 方 法}

\section{1. 対 象 者}

本研究の対象者は体育系大学の運動部に所属する女子 学生49名であった。このうち, 尿サンプルに不備のあっ た 1 名, 食事記録に不備のあった 1 名, 測定期間中の体 重変化の有無が確認できなかった 5 名, 体重補正済み TEE (calculated Total Energy Expenditure: cTEE) が基 礎代謝量（Basal Metabolic Rate: BMR）を下回った 4 名 を除外した計 38 名を解析の対象とした。内訳は陸上 9 名・水泳 10 名・新体操 7 名・ラクロス 12 名であった。対 象者は, 全日本学生選手権あるいは関東学生選手権に出 場する競技レベルであった。

\section{2. 研究計画}

調査は2005〜2008年の通常トレーニング期に実施し， 身長，体重，体脂肪率および FFM， BMR，TEE の測定 および食事調査を行った。TEE の測定は 7 日間にわたっ て行い，同期間に食事調査を実施した。BMR は TEE 測 定期間の前後のうち，測定期間に出来る限り近い卵胞期 に測定した。身長は TEE 測定の初日に測定し，体重は対 象者自身が 1 日 1 回測定した。体脂肪率および FFM の 測定は, TEE 測定期間の終了後 4 日以内に実施した。

本研究は, (独) 国立健康・栄養研究所「人間を対象と する生物医学的研究に関する倫理委員会」の承認を得て, ヘルシンキ宣言の精神を遵守して実施した。対象者には あらかじめ調查の目的，内容，危険性などを説明し，本 人および20歳未満の選手は併せて保護者から, 文書によ る同意を得た。

3. 測 定 項 目

1 ) 身体計測

身長は身長計（ST-2M，（株)ヤガミ，愛知）を用いて 測定した。体重は体重計（UC-321，（株）エー・アンド・ デイ，東京）を対象者に配布し，早朝空腹時に測定する よう依頼した。体脂肪率および FFM は二重エネルギー X 線吸収測定法（QDR4500A, Hologic Inc., Bedford, MA, USA）を用いて测定した。BMI は体重 $(\mathrm{kg}) /$ 身長 $(\mathrm{m})^{2}$ より求めた。

\section{2) BMR の測定}

対象者は測定前日の夜 9 時までに食事を済ませて宿泊 施設に宿泊した。翌朝，室温 $20 \sim 25^{\circ} \mathrm{C}$ の条件下で30分 以上，仰臥位にて安静にした後，仰臥位のまま10分間の 呼気をダグラスバッグに 2 回採集した。採集後は直ちに, 呼気ガス分析装置 (陸上, 水泳, 新体操 : AE-300SRC,

ミナト医科学(株), 大阪, ラクロス：ARCO-1000, (有) アルコシステム, 千葉）を用いて，呼気中の酸素濃度お 
よび二酸化炭素濃度を測定した。その後, 乾式ガスメー 夕（DC-5，（株) シナガワ, 東京）を用いて呼気量を測定 した。それらの測定值から酸素摂取量と二酸化炭素産生 量を算出し, Weir ${ }^{20)}$ の式により 1 分間当たりの BMR を 計算した。この值を 1,440 分に換算し， 1 日当たりの BMR（kcal/day）とした。

3 ) DLW 法による TEE の測定

10.0 atom $\%{ }^{18} \mathrm{O}$ (大陽日酸(株), 東京) と 99.9 atom $\%{ }^{2} \mathrm{H}$ (Cambridge Isotope Laboratories Inc., Andover, MA, USA）の混合液により, 体重 $1 \mathrm{~kg}$ 当たり $0.14 \mathrm{~g} の{ }^{18} \mathrm{O}$ と $0.06 \mathrm{~g}$ の ${ }^{2} \mathrm{H}$ を経口投与した。対象者は早朝空腹時に 尿の採取と体重測定を行った後にDLWを摂取した。陸 上は, 投与の 4 時間後および 5 時間後と, 翌日（2 回）, 8 日後（2 回）の規定された時間に採尿した。水泳, 新 体操およびラクロスは, 翌日から 8 日目まで, 1 日 1 回, 10分以内の範囲でのほぼ同時刻に採尿し，採尿した時刻 を記録した。

サンプルは密閉した状態で, 分析まで $-30^{\circ} \mathrm{C} て ゙$ 保存し た。 ${ }^{2} \mathrm{H}$ は白金を触媒として $\mathrm{H}_{2}$ ガスで, ${ }^{18} \mathrm{O}$ は $\mathrm{CO}_{2}$ ガス で平衡法により前処理を行った後, ${ }^{2} \mathrm{H}$ および ${ }^{18} \mathrm{O}$ の安定 同位体比を質量比分析計 (Finnigan Delta Plus, Thermo Fisher Scientific Inc., Waltham, MA, USA）により分析し た。

陸上の ${ }^{2} \mathrm{H}$ および ${ }^{18} \mathrm{O}$ の希釈容積 $(\mathrm{N})(\mathrm{mol})$ は, 投与 4 時間後および 5 時間後のサンプル尿の同位体比 $(\delta \mathrm{s})$ から, $\mathrm{N}=[\mathrm{WA}(\delta \mathrm{a}-\delta \mathrm{t})] /[18.02 \mathrm{a}(\delta \mathrm{s}-\delta \mathrm{b})]$ により 求めた。水泳, 新体操掞よびラクロスの $\mathrm{N}(\mathrm{mol})$ は, 尿 中の安定同位体比から求めた標準化した安定同位体濃度 $([18.02 \mathrm{a}(\delta \mathrm{s}-\delta \mathrm{b})] /[\mathrm{WA}(\delta \mathrm{a}-\delta \mathrm{t})])$ を対数変換した 值と DLW 投与後の経過時間との直線回帰式から, 時間 0 における安定同位体濃度の逆数とした。W は同位体比 分析の際に DLW を希釈するのに用いた飲料水の量 $(\mathrm{g})$, $\mathrm{A}$ は投与した DLW の量 $(\mathrm{g})$, a は希釈した DLW の量, $\delta \mathrm{a}$ は希釈した DLW における同位体比, $\delta \mathrm{t}$ は DLW の希 釈に用いた飲料水の同位体比, $\delta \mathrm{s}$ はサンプル尿の同位体 比, $\delta \mathrm{b}$ はベースラインでの尿の同位体比である。 ${ }^{2} \mathrm{H}$ か ら求めた $\mathrm{N}$ を1.041で除したものと, ${ }^{18} \mathrm{O}$ から求めた $\mathrm{N}$ を1.007で除したものの平均值を, 安定同位体の $\mathrm{N}$ とし た。安定同位体の減衰率 $(\mathrm{k})$ は, 陸上は $\mathrm{k}=[\ln （ \delta \mathrm{f}-$ $\delta \mathrm{b})-\ln (\delta \mathrm{i}-\delta \mathrm{b})] / \mathrm{t}$ から求めた。 $\delta \mathrm{f}$ は 8 日後の尿中 の同位体比, $\delta \mathrm{b}$ はベースライン尿の同位体比, $\delta \mathrm{i}$ は投 与翌日の同位体比, $\mathrm{t}$ は測定期間（日）である。水泳, 新 体操およびラクロスでは，標準化した安定同位体濃度の 対数と投与時刻からの経過時間の直線回帰式における傾 きを，安定同位体の減衰率（k）とした。
二酸化炭素の排出量 $\left(\mathrm{rCO}_{2}\right)$ は, $\mathrm{rCO}_{2}(\mathrm{~L} /$ day $)=$ $0.4554 \times$ 総体水分量 $\times(1.007 \mathrm{ko}-1.041 \mathrm{kh})$ により求め た。 ko は ${ }^{18} \mathrm{O}$ の減衰率, $\mathrm{kh}$ は ${ }^{2} \mathrm{H}$ の減衰率であり, 総体 水分量は安定同位体の希釈容積（N）とした。DLW 法に おいては，全期間を通じた呼吸商の直接測定が不可能で ある。そのため, 大きな体重変動のないエネルギーバラ ンスのとれた状態では, 食物商を使用して TEE を求める ことが最も適切とされている ${ }^{21)}$ 。本研究の食物商は, 調 查時期に近い年度に実施された国民健康・栄養調査結 果 ${ }^{22)}$ における，対象者と同年代の主要栄養素摂取量から Black ら ${ }^{23)}$ の式を用いて算出し, TEE は Weir の式 ${ }^{20)} よ$ り求めた。PAL は TEE を BMR で除して求めた。

\section{4 ）食事調査}

TEE の測定と同期間に, 自己記入式の食事記録法（秤 量法と目安量法の併用）による食事調查を実施した。対 象者に食事記録用紙，デジタルカメラ（COOLPIX L12, (株) Nikon, 東京), デジタルソーラークッキングスケー ル（ルイール1155, （株）タニタ，東京）を配布した。食 事記録用紙に摂取した時間・食べた場所・料理名（市販 食品はその名称) ・材料名・重量を記入するように依頼し た。併せて食事摂取前にデジタルカメラによる撮影を依 頼した。食品の重量は可能な限り秤量し, 秤量が困難な 場合のみ目安量を記入した。記録用紙の回収時にデジタ ルカメラの映像と記録用紙とを照合しながら, 食事調査 のトレーニングを受けた管理栄養士が対象者に対し，食 事記録内容の確認を行った。栄養素および食品群別の摂 取量は, 5 訂増補日本食品標準成分表に準拠した栄養計 算ソフト（エクセル栄養君 Ver. 4.5，（株)建帛社，東京） を用いて計算した。食品の分類は，5訂増補日本食品標 準成分表に基づいて18食品群を使用した。

1 日あたりの平均食事回数を食事記録から求めた。「食 事」は国民健康・栄養調査 ${ }^{22)}$ における久食の定義「砂 糖・ミルクを加えないお茶類（日本茶・コーヒー・紅茶 など)，水及び錠剂・カプセル・顆粒状のビタミン・ミネ ラルのみをとった場合も欠食に含める」を参考とし，こ れ以外の食品を摂取した場合とした。

\section{5 ) 統計解析}

TEE を基準として TEI の評価誤差を検討する際に，体 重変化が生じた場合は，あらかじめ TEE を調整しておく 必要がある ${ }^{24)}$ 。体重 $1 \mathrm{~kg}$ は約 $30,000 \mathrm{~kJ}$ に相当するこ

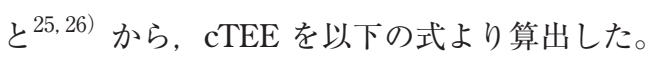

cTEE $(\mathrm{kcal})=$

体重変化量 $(\mathrm{kg}) \times 30,000(\mathrm{~kJ}) / 4.184(\mathrm{kcal}) /$

7 (日) + TEE (kcal)

また，TEI 評価誤差は下記の式により算出した。 
TEI 評価誤差 $(\%)=($ TEI $-\mathrm{cTEE}) / \mathrm{cTEE} \times 100$

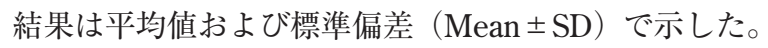
競技間の比較は一元配置分散分析により行い, Post hoc 検定は Tukey の HSD 検定を使用した。TEE 測定期間の 初日および最終日の体重の比較には, 対応のある $t$ 検定 を用いた。

TEI 評価䛊差に関連する要因の検討のために, 対象者 を TEI 評価誤差に基づき 2 群に分類した。TEI 評価誤差 の絶対值が小さいほど高精度であるとし, TEI 評価誤差 の絶対值が 0 に近い方から19名までを高精度群とした。 残りの19名のうち, 過小評価であった15名を過小評価群 とした。残りの 4 名は過大評価であった。身体組成, エ ネルギー消費量, エネルギー摂取量, 食事摂取状況の比 較は高精度群と過小評価群との間でのみ, Student の $t$ 検 定により行った。 2 群間の比較で有意差のあった項目の うち, TEE, 菓子類摂取量, 食事回数, 脂質エネルギー 比率の 4 項目に, 各競技種目への所属 (陸上, 水泳, 新 体操, ラクロスの各運動部に 1 : 所属している, 0 : 所 属していない) をダミー変数として加えた計 8 項目を独 立変数, 高精度群および過小評価群への分類（1：高精 度群, 0 : 過小評価群) を従属変数とし, 二項ロジス ティック回帰分析を行った。なお, 本研究において, 脂 質エネルギー比率と炭水化物エネルギー比率は相互に影 響し合っており，両方を独立変数として投入することは 望ましくないと判断し, 先行研究 ${ }^{12)}$ において TEI 評価誤 差との関連が指摘されている脂質エネルギー比率のみを 投入した。

得られたデータの統計処理には, 統計ソフト Dr. SPSS II for Windows（SPSS Inc., Chicago, IL, USA）を使用し
た。有意水準は両側検定ですべて $5 \%$ 未満とした。

\section{III. 結 果}

対象者の特性を表 1 に示した。いずれの競技種目にお いても, 調査期間の初日と最終日の体重に有意差はな かった。BMI は, 新体操が水泳およびラクロスと比較し て有意に低かった。体脂肪率は，水泳および新体操がラ クロスよりも有意に低值であった。FFM に有意差はな かった。

DLW 法により測定した 1 日あたりの TEE は，競技種 目間に有意差はなかった（表 2 ）。1 日あたりの BMR, 体重および FFM 当たりの BMR は，競技種目間に有意差 はなかった。PAL も競技間に有意差はなく，1.75〜3.53 の範囲であった。cTEEにも競技種目間に有意差はな かった。TEI は新体操 $(1,852 \pm 314 \mathrm{kcal} / \mathrm{day})$ が水泳 $(2,455 \pm 297 \mathrm{kcal} / \mathrm{day})$ と比較して有意に低值であった。 TEI 評価誤差は陸上 $-13.6 \pm 24.1 \%$, 水泳 $-13.3 \pm 14.3 \%$, 新体操 $-42.0 \pm 15.3 \%$, ラクロス $-2.8 \pm 38.3 \%$ であり, 新体操でラクロスに比べて有意に過小評価していた。評 価誤差が正の值であった者は, 陸上に 2 名, 水泳に 2 名, ラクロスに 4 名含まれ, 新体操は全員が負の值であった。 TEI と cTEE の関係について, 分布に種目による明確な 違いはみられず，いずれの種目においてもばらつきが大 きかった（図 1 )。食事摂取状況の比較では, 新体操は, ラクロスに比べて穀類と油脂類が有意に少なかった（穀 類 : $p=0.002$, 新体操 $258.9 \pm 78.6 \mathrm{~g} / \mathrm{day}$, ラクロス $506.1 \pm 103.4 \mathrm{~g} / \mathrm{day}$, 油脂類 : $p=0.012$, 新体操 $8.7 \pm$ $3.2 \mathrm{~g} / \mathrm{day}$, ラクロス $15.1 \pm 4.5 \mathrm{~g} / \mathrm{day})$ 。水泳はラクロ

表 1 対象者特性

\begin{tabular}{|c|c|c|c|c|c|c|}
\hline & $\begin{array}{c}\text { 陸上中長距離 } \\
\quad(n=9)\end{array}$ & $\begin{array}{l}\text { 水 泳 } \\
(n=10)\end{array}$ & $\begin{array}{l}\text { 新体操 } \\
(n=7)\end{array}$ & $\begin{array}{c}\text { ラクロス } \\
(n=12)\end{array}$ & $\begin{array}{l}\text { 全競技 } \\
(n=38)\end{array}$ & 有意確率 \\
\hline 年齢（歳） & $20.1 \pm 0.6^{\mathrm{d}}$ & $20.2 \pm 1.0^{\mathrm{d}}$ & $19.7 \pm 0.4^{\mathrm{d}}$ & $21.0 \pm 0.4^{\mathrm{a}, \mathrm{b}, \mathrm{c}}$ & $20.3 \pm 0.8$ & 0.002 \\
\hline 身長（cm） & $163.7 \pm 6.7^{\mathrm{d}}$ & $162.1 \pm 4.5$ & $162.0 \pm 2.9$ & $157.7 \pm 4.2^{\mathrm{a}}$ & $161.1 \pm 5.2$ & 0.039 \\
\hline \multicolumn{7}{|l|}{ 体重 } \\
\hline 調査初日（kg） & $54.1 \pm 8.0$ & $58.6 \pm 5.6^{\mathrm{c}}$ & $50.0 \pm 2.2^{\mathrm{b}}$ & $56.2 \pm 4.4$ & $55.3 \pm 6.0$ & 0.023 \\
\hline 調査最終日（kg） & $54.1 \pm 8.0$ & $58.5 \pm 5.5^{c}$ & $50.3 \pm 2.3^{\mathrm{b}}$ & $56.0 \pm 4.4$ & $55.2 \pm 6.0$ & 0.042 \\
\hline 変化量（kg） & $\pm 0.0 \pm 0.5$ & $-0.2 \pm 0.6$ & $+0.4 \pm 0.5^{\mathrm{d}}$ & $-0.4 \pm 0.7^{\mathrm{c}}$ & $-0.1 \pm 0.6$ & 0.065 \\
\hline BMI $\left(\mathrm{kg} / \mathrm{m}^{2}\right)$ & $20.2 \pm 2.3$ & $22.3 \pm 2.7^{\mathrm{c}}$ & $18.8 \pm 0.9^{\mathrm{b}, \mathrm{d}}$ & $22.8 \pm 1.5^{\mathrm{c}}$ & $21.3 \pm 2.5$ & 0.001 \\
\hline 体脂肪率（\%） & $19.3 \pm 3.8$ & $22.4 \pm 3.5^{\mathrm{c}}$ & $17.9 \pm 2.3^{\mathrm{b}, \mathrm{d}}$ & $22.4 \pm 2.5^{\mathrm{c}}$ & $20.8 \pm 3.5$ & 0.007 \\
\hline 除脂肪量（kg） & $44.3 \pm 4.7$ & $46.3 \pm 2.7$ & $42.5 \pm 2.1$ & $44.4 \pm 3.2$ & $44.5 \pm 3.5$ & 0.16 \\
\hline
\end{tabular}

平均值 \pm 標準偏差。

BMI: Body Mass Index

二重標識水法による総エネルギー消費量測定および食事調査の初日と最終日に体重を測定。

$†$ 競技種目差に関する一元配置分散分析による有意確率。

Tukey の HSD 検定により， $\mathrm{a}$ ：陸上中長距離， $\mathrm{b}$ ：水泳， $\mathrm{c}$ ：新体操， $\mathrm{d} ：$ ラクロスとの間に有意差あり $(p<0.05)$ 。 
表 2 エネルギーの消費量と摂取量に関する項目

\begin{tabular}{|c|c|c|c|c|c|c|}
\hline & $\begin{array}{c}\text { 陸上中長距離 } \\
\quad(n=9)\end{array}$ & $\begin{array}{l}\text { 水 泳 } \\
(n=10)\end{array}$ & $\begin{array}{l}\text { 新体操 } \\
(n=7)\end{array}$ & $\begin{array}{l}\text { ラクロス } \\
(n=12)\end{array}$ & $\begin{array}{l}\text { 全競技 } \\
(n=38)\end{array}$ & 有意確率 \\
\hline 総エネルギー消費量（kcal/day） & $2,673 \pm 620$ & $3,077 \pm 346$ & $2,910 \pm 224$ & $2,910 \pm 277$ & $2,898 \pm 405$ & 0.19 \\
\hline \multicolumn{7}{|l|}{ 基礎代謝量 } \\
\hline 1 日あたり（kcal/day） & $1,200 \pm 222$ & $1,300 \pm 209$ & $1,121 \pm 150$ & $1,220 \pm 168$ & $1,218 \pm 192$ & 0.30 \\
\hline 体重あたり（kcal/day/kg） & $22.1 \pm 2.1$ & $22.3 \pm 3.5$ & $22.3 \pm 2.9$ & $21.7 \pm 2.3$ & $22.1 \pm 2.7$ & 0.94 \\
\hline 除脂肪量あたり（kcal/day/kg） & $30.4 \pm 4.1$ & $29.8 \pm 4.6$ & $29.5 \pm 3.5$ & $31.5 \pm 4.0$ & $30.4 \pm 4.0$ & 0.73 \\
\hline 身体活動レベル & $2.23 \pm 0.33$ & $2.45 \pm 0.41$ & $2.65 \pm 0.47$ & $2.44 \pm 0.47$ & $2.43 \pm 0.43$ & 0.30 \\
\hline 体重補正済み総エネルギー消費量（kcal/day） & $2,673 \pm 922$ & $2,923 \pm 749$ & $3,276 \pm 497$ & $2,628 \pm 701$ & $2,836 \pm 752$ & 0.24 \\
\hline 総エネルギー摂取量（kcal/day） & $2,151 \pm 434$ & $2,455 \pm 297^{\mathrm{c}}$ & $1,852 \pm 314^{\mathrm{b}}$ & $2,329 \pm 407$ & $2,232 \pm 416$ & 0.015 \\
\hline \multicolumn{7}{|l|}{ 主要栄養素のエネルギー比率 } \\
\hline たんぱく質（\%） & $14.1 \pm 1.8^{\mathrm{b}}$ & $12.1 \pm 1.2^{\mathrm{a}}$ & $12.4 \pm 1.3$ & $13.2 \pm 1.3$ & $13.0 \pm 1.6$ & 0.019 \\
\hline 脂質（\%） & $28.3 \pm 2.5$ & $28.2 \pm 3.8$ & $31.3 \pm 3.3$ & $31.5 \pm 3.1$ & $29.8 \pm 3.5$ & 0.036 \\
\hline 炭水化物（\%） & $56.4 \pm 3.2$ & $58.3 \pm 3.8^{\mathrm{d}}$ & $55.6 \pm 2.2$ & $53.3 \pm 3.7^{\mathrm{b}}$ & $55.8 \pm 3.8$ & 0.015 \\
\hline 総エネルギー摂取量の評価誤差（\%) & $-13.6 \pm 24.1$ & $-13.3 \pm 14.3$ & $-42.0 \pm 15.3^{\mathrm{d}}$ & $-2.8 \pm 38.3^{\mathrm{c}}$ & $-15.3 \pm 28.9$ & 0.033 \\
\hline
\end{tabular}

平均値士標準偏差。

身体活動レベルは総エネルギー消費量を基礎代謝量で除した值。

体重補正済み総エネルギー消費量（kcal）は体重変化量を考虑して算出した 1 日あたりのエネルギーの過不足量を二重標識水法により測定した総エネ ルギー消費量に加えた值。

総エネルギー摂取量の評価誤差（\%）は（総エネルギー摂取量－体重補正済み総エネルギー消費量）／体重補正済み総エネルギー消費量 $\times 100$ 。

$\dagger$ 競技種目差に関する一元配置分散分析による有意確率。

Tukey の HSD 検定により， a ：陸上中長距離, $\mathrm{b}$ ：水泳， c ：新体操， $\mathrm{d} ：$ ラクロスとの間に有意差あり $(p<0.05)$ 。

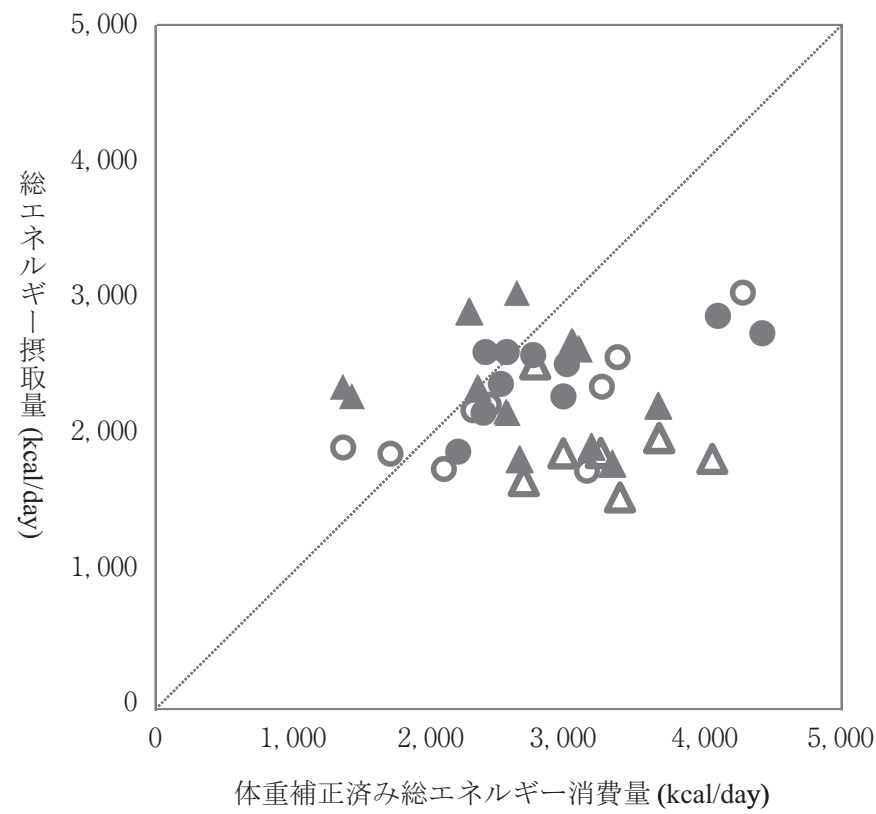

図 1 総エネルギー摂取量と体重補正済み総エネルギー消費量の関係

○は陸上

は水泳, $\triangle$ は新体操,

ヘはラクロスを示す。

スより魚介類が有意に少なく, 炭水化物エネルギー比率 は有意に高かった。また, 水泳は新体操より穀類が有意 に多く，陸上よりたんぱく質エネルギー比率が有意に少 なかった。ラクロスは陸上より嗜好飲料類の摂取量が有 意に少なかった。食事回数は, 種目間に有意差はなかっ た。

高精度群と過小評価群の群間比較の結果を表 3 に示し た。TEI 評価誤差は, 高精度群が $-8.4 \pm 10.7 \%$ （值の範
囲： $-24.8 \%$ + $14.5 \%)$ ，過小評価群は $-40.9 \pm 8.8 \%$ （-56.3\%〜 - 28.7\%）であった。高精度群は過小評価 群と比較して, TEE, cTEE および脂質エネルギー比率 が有意に低值であり, TEI, 菓子類摂取量, 食事回数, 炭 水化物エネルギー比率が有意に高值であった。摂取量は

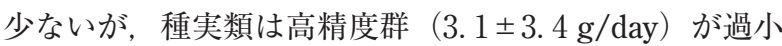

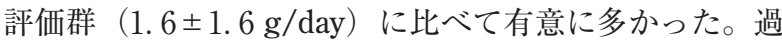
大評価の者の cTEE は $1,613 \pm 443 \mathrm{kcal} /$ day, たんぱく質, 
表 3 評価誤差の有無により分類した 2 群間の比較

\begin{tabular}{|c|c|c|c|}
\hline & $\begin{array}{c}\text { 高精度群 } \\
(n=19)\end{array}$ & $\begin{array}{c}\text { 過小評価群 } \\
\quad(n=15)\end{array}$ & 有意確率 \\
\hline 人数（陸上／水泳／新体操／ラクロス） (名) & $5 / 8 / 1 / 5$ & $3 / 2 / 6 / 4$ & \\
\hline 体重（kg） & $54.9 \pm 6.5$ & $55.7 \pm 6.2$ & 0.73 \\
\hline BMI $\left(\mathrm{kg} / \mathrm{m}^{2}\right)$ & $21.7 \pm 2.6$ & $20.8 \pm 2.6$ & 0.85 \\
\hline 体脂肪率（\%） & $21.4 \pm 3.8$ & $20.0 \pm 3.2$ & 0.27 \\
\hline 除脂肪量（kg） & $43.9 \pm 3.5$ & $45.7 \pm 3.5$ & 0.13 \\
\hline 総エネルギー消費量（kcal/day） & $2,749 \pm 418$ & $3,114 \pm 304$ & 0.008 \\
\hline 基礎代謝量（kcal/day） & $1,215 \pm 232$ & $1,251 \pm 116$ & 0.56 \\
\hline 身体活動レベル & $2.34 \pm 0.49$ & $2.50 \pm 0.24$ & 0.22 \\
\hline 体重補正済み総エネルギー消費量（kcal/day） & $2,587 \pm 396$ & $3,476 \pm 548$ & $<0.001$ \\
\hline 総エネルギー摂取量（kcal/day） & $2,350 \pm 328$ & $2,054 \pm 474$ & 0.039 \\
\hline 菓子類摂取量（g/day） & $99.3 \pm 43.4$ & $60.7 \pm 33.1$ & 0.007 \\
\hline 食事回数（回/day） & $4.27 \pm 0.83$ & $3.53 \pm 0.86$ & 0.016 \\
\hline 脂質エネルギー比率（\%） & $28.2 \pm 2.9$ & $31.4 \pm 3.6$ & 0.008 \\
\hline 炭水化物エネルギー比率（\%） & $57.6 \pm 3.2$ & $54.2 \pm 3.9$ & 0.008 \\
\hline
\end{tabular}

平均值 \pm 標準偏差。

BMI: Body Mass Index

評価誤差の絶対值が 0 に近い方から 19 名を高精度群，残りの19名のうち過小評価であった者 15 名を過小評 価群とした。

各群の評価誤差の平均值士標準偏差と值の範囲は, 高精度群 : $-8.4 \pm 10.7 \%(-24.8 \% \sim+14.5 \%)$, 過小 評価群 : $-40.9 \pm 8.8 \%(-56.3 \% \sim-28.7 \%)$ 。

$\dagger$ Student $の t$ 検定による有意確率。

表 4 評価誤差の有無に関連する要因

\begin{tabular}{lcccc}
\hline & 単位変化量 & オッズ比 & $(95 \%$ 信頼区間 $)$ & 有意確率 \\
\hline 総エネルギー消費量 $(\mathrm{kcal} / \mathrm{day})$ & 100 & 0.583 & $(0.349 \sim 0.976)$ & 0.040 \\
脂質エネルギー比率 $(\%)$ & 1 & 0.547 & $(0.291 \sim 1.03)$ & 0.060 \\
菓子類摂取量 $(\mathrm{g} / \mathrm{day})$ & 1 & 1.06 & $(0.995 \sim 1.13)$ & 0.071 \\
水泳部への所属 & 1 & 88.1 & $(0.601 \sim 12,927)$ & 0.078 \\
\hline
\end{tabular}

総エネルギー消費量, 菓子類摂取量, 食事回数, 脂質エネルギー比率に, 競技種目をダミー変数（陸上, 水泳, 新体操, ラクロスのそれぞれに 1 : 所属している，0：所属していない）として加えた計 8 項目を 独立変数, エネルギー摂取量の評価誤差の有無（1：高精度群, 0 : 過小評価群) を従属変数として, 変 数増加法による二項ロジスティック回帰分析を行った。

変数の選択基準として, 独立変数の有意確率が $5 \%$ 以下でその変数を投入し, $10 \%$ 以上で除去するよう設 定した。

脂質，炭水化物のエネルギー比率はそれぞれ，13.9 $2.5 \%, 31.7 \pm 2.0 \%, 53.4 \pm 1.7 \%$ であった。二項ロジ スティック回帰分析によると, 高精度群への分類に関連 する項目として選択されたのは, TEE, 菓子類摂取量, 脂質エネルギー比率, 水泳部への所属の 4 項目であり, TEE が小さいことが TEI を高精度に評価することに独立 して関連していた（表 4 ）。

\section{N. 考 察}

本研究は, 1 つの研究で複数の種目間の TEI 評価誤差 について検討し, 新体操選手がラクロス選手よりも有意
に過小評価していたことを明らかにした。また，本研究 は, 先行研究 $4,9,12 \sim 15)$ で一般人において評価誤差との関 連が指摘されている TEE, 菓子類摂取量, 食事回数, エ ネルギー比率が，スポーツ選手でも評価誤差の関連要因 となることを明らかにした。

\section{1. 競技種目の影響}

本研究では競技特性の異なる 4 つの競技種目を対象と して，通常トレーニング期における競技種目別の TEI 評 価誤差について検討した。新体操がラクロスに比べて TEI を有意に過小評価しており，TEI 評価誤差は新体操 選手全員が負の值であった。ラクロスは TEI 評価誤差の 平均值が小さく, 標準偏差は他種目と比べて大きかった。 
これは, ラクロスには比較的大きく過大評価をする選手 と過小評価をする選手がいたことによると考えられる。 Fogelholm ら ${ }^{27)}$ は, 審美系競技 (新体操, フィギュアス ケート）の選手が女性サッカー選手や一般女性と比較し て TEI を過小評価する傾向があることを報告しており， 本研究においてもこれと同様の傾向が確認された。一般 人では，菓子類や揚げ物など「食べると太りそう」と認 識されている食品は過小に評価されることが指摘されて いる ${ }^{28)}$ 。審美系競技選手では, 体重管理を日ごろから厳 しく行っていることが多く29)，「太りそうな食べ物」への 認識が特に強いと推測できる。新体操がラクロスに比べ て, 穀類と油脂類の摂取量が有意に少なかったことから, 新体操選手の方がラクロス選手よりも体重コントロール のためにこれらの食品群の摂取量を制限している，ある いは摂取した食品を記録しなかったり，実際の摂取量よ りも少なく記録したりする傾向が強かった可能性が考え られる。

審美系競技の選手と同様に，持久系競技種目の選手は 体重が軽い方が高いパフォーマンスを発揮できるため, 体重を減らすことへの意識が強いことが推測できる。し かしながら, 本研究における陸上中長距離選手の評価誤 差は水泳選手と同程度であった。この理由としては, 本 研究対象者の所属するクラブでは中距離と長距離のト レーニングをどちらも行っていたため, 選手の専門種目 が持久系に特化しておらず，持久系競技種目としての競 技特性があまり強く示されなかった可能性が考えられる。

水泳選手はラクロス選手と比較して, 炭水化物エネル ギー比率が有意に高值であったが, 評価誤差に有意差が なかった。また，陸上選手は炭水化物エネルギー比率に 他の種目との有意差がなく, 種目による食事内容の違い がみられなかった。したがって, 本研究における種目間 の比較では, 炭水化物エネルギー比率と評価誤差との関 連は見られなかった。

本研究では, 体重は新体操と水泳に, BMI および体脂 肪率は新体操と水泳およびラクロスとの間に有意差がみ られたものの, 予測していた競技種目ごとの身体組成の 差が明確にみられなかった。したがって，トレーニング 内容や食事内容にも競技種目による明らかな違いがな かったと推察される。また, TEI 評価誤差, エネルギー 比率や食品群別摂取量は, 同一競技内での個人差が大き く, ラクロスと新体操の比較以外では, 競技種目による TEI 評価誤差の違いを明らかにできなかった。

\section{2. 食事摂取状況の影響}

高精度群は過小評価群と比較して, TEI と菓子類摂取 量が有意に高值であった。 Livingstone ら ${ }^{30)}$ は, 記録さ
れた TEI が低い者の方が高い者よりも，申告された菓子 類の摂取量が少ない傾向がみられたことを報告している。 本研究の過小評価群では, TEI および菓子類摂取量が高 精度群よりも有意に少なかった。一般的に「健康に良く なさそう」「食べると太りそう」と認識されている食品 は，摂取した量よりも少なく記録する傾向がある ${ }^{28)}$ 。過 小評価群は菓子類を望ましくない食品であるとする認識 が高精度群よりも強く，実際には菓子類を摂取していた としても，意図的に記録をしない，あるいは少なく申告 をしていた可能性が考えられる。

高精度群の食事の特徵としては, 過小評価群より菓子 類摂取量と炭水化物エネルギー比率が有意に高值であり, 脂質エネルギー比率が有意に低值なことがあげられる。 たんぱく質エネルギー比率と，菓子類および種実類以外 の食品群の摂取量に, 高精度群と過小評価群で有意差は なかった。一般人においては, 本研究対象者と同年代の 女性で, 過小評価群よりも高精度群の炭水化物の摂取比 率が低く，脂質の摂取比率が高かった ${ }^{13)}$ 。このことから， 炭水化物と脂質の摂取比率が相互に影響していると考え られるが, 主要栄養素の摂取比率についての詳細な考察 はなされていなかった ${ }^{13)}$ 。本研究のスポーツ選手では, 過小評価群よりも高精度群の炭水化物エネルギー比率が 高值, 脂質エネルギー比率が低值であり, 先行研究 ${ }^{13)}$ と 異なる結果であった。本研究でも, 炭水化物と脂質の工 ネルギー比率が相互に大きく影響しているため, 菓子類 摂取量, 炭水化物エネルギー比率, 脂質エネルギー比率 がどのように TEI 評価誤差に関連しているかは明らかに できなかった。二項ロジスティック回帰分析においても, 脂質エネルギー比率は独立して関連している要因とはな らなかった。菓子類の内容が高精度群と過小評価群で異 なるかを検討するために, 菓子類からの炭水化物と脂質 のエネルギー比率を比較した。菓子類の炭水化物と脂質 のエネルギー比率はそれぞれ，高精度群が56.2 $56.7 \%$, $36.0 \pm 7.4 \%$, 過小評価群が $52.2 \pm 5.8 \%$, 40.8 $0.3 \%$ であり明らかな差は見られなかった。

食事回数は, 高精度群が過小評価群より有意に多かっ たことから，高精度群が間食をより正確に記録すること が出来たと考えられる。高田ら ${ }^{4)}$ は日本人を対象とした 研究で，食事回数が少ない者ほど過小に評価する傾向が みられたことを指摘しており，この原因として，間食を しない食生活をしている者が過小評価する傾向にある可 能性と，間食などの記録漏れにより過小評価が生じた可 能性の両方があるとしている。本研究において食事回数 と食品群別摂取量との相関関係を検討したところ，嗜好 飲料類の摂取量との間に有意な正の相関がみられた。本 
研究ではエネルギーを有する飲料のみを摂取した場合も 1 回分の食事と見なしており, 飲料のみを間食とした場 合に正確に記録できなかったために, 過小評価を引き起 こした可能性が考えられる。しかしながら, 高田ら ${ }^{4)}$ が 指摘している通り, 間食をしない食生活をしている者が 過小評価する傾向がある可能性も捨てられない。した がって, 今後は食事内容と食事区分に着目した検討が必 要であると考える。

\section{TEE の影響}

高精度群は過小評価群と比較して, TEE が有意に低值 であった。これはスポーツ選手以外の者を対象とした先 行研究 $^{15,16)}$ と同様の結果であった。Bandini ら ${ }^{15)}$ は 8 12歳の女子について, 7 日間の目安量法による食事記録 法から求めた TEI と DLW 法から求めた TEE の差と,

TEE との間に有意な正の相関がみられたことを報告して いる。Barnard ら ${ }^{16)}$ は22〜 59歳の男女で, TEE が大き くなるほど 7 日間の秤量法による食事記録法から求めた TEI の評価誤差が大きくなることを報告している。

本研究において, TEE が小さいことは高精度群への分 類に有意に関連していたが, TEI の評価誤差に TEEの絶 対值が影響するのか，あるいは PAL が影響するのかにつ いては, 慎重に検討する必要がある。Okubo ら ${ }^{5)}$ は日本 人男女について, DLW 法により測定した TEE を用いて 算出した PAL と TEI 評価誤差との間に, 男女とも有意な 負の相関があったと報告している。しかし， Okubo ら ${ }^{5)}$ は TEE と TEI 評価䛊差との関連性は検討しておらず，ま た，PALの算出に必要な BMR に推定值を用いているた め, 実測值を使用している本研究と単純に比較すること は困難である。一方, 本研究において高精度群と過小評 価群との間で, TEE は過小評価群が有意に高かったが, PAL に有意差はみられなかった。本研究では対象者の詳 細な活動内容を把握していないため, TEE の違いがト レーニングなどの選手特有の活動に由来するか, トレー ニング以外の日常生活における活動に由来するかは不明 である。今後は活動内容の評価も併せて検討し, TEE と TEI 評価誤差との関連にスポーツ選手と一般人とで違い がみられるかを解明すること, 食事記録法による食事調 査を実施する際の, 対象者に応じた注意点を明らかにす ることが必要と考える。

\section{4. 本研究の課題}

本研究において，4つの限界が挙げられる。第 1 に, 意図した競技種目による体格や食事摂取内容の差が見ら れなかったこと, および対象者数が少なかったことであ る。本研究では, 体格や食事摂取内容が大きく異なると 予測して, 陸上中長距離, 水泳, 新体操, ラクロスを対
象とした。しかし，予測した身体組成や食事摂取状況の 差が明確にみられず，競技種目と TEI 評価誤差との関連 が明らかにできなかった。特に陸上は, 長距離種目の選 手に研究協力を依頼したが, 対象とした部では中距離と 長距離のトレーニングをどちらも行っていたため，持久 性種目の特徴がみられなかった。また，本研究では同一 競技内で TEI 評価誤差の結果に大きな個人差があった が，競技ごとに対象人数が少なかったために，競技種目 内で評価誤差に影響する要因を比較することは困難で あった。競技種目の違いに着目して TEI 評価誤差への影 響要因を明らかにするためには，対象とする競技種目あ るいはそのレベル，および 1 種目あたりの対象者数を再 考した上で，さらなる検討が必要であろう。

第 2 に，長期的な体重変化のモニタリングを実施して いないことである。Goris ら ${ }^{31)}$ は, 食事摂取量の誤差は 測定期間中の体重変化のみから評価するのではなく，測 定期間以外の時期の体重変化を考慮して評価するのが望 ましいとしている。今後は測定期間中の体重測定に加え て, 測定期間前後の体重測定を実施し, 体重変化を長期 的に観察する必要があると考える。

第 3 に, TEI 評価誤差に関連する要因として検討した 項目が限られていたことである。本研究では, 競技種目, 身体組成, 食事摂取状況に焦点をあてた。しかしながら, 一般人を対象とした先行研究において, 体格へのイメー ジといった心理的要因や, 経済状況, 教育水準などの社 会的要因が, TEI 評価誤差に関連することが報告されて いる11)。本研究では, 競技種目により有利となる体格が 異なることが, TEI 評価誤差に影響を与えると予測して 検討を行った。新体操選手が過小評価群に多く含まれて いたことは, 新体操選手が日常的に体重のコントロール を厳しく行っていることと関連していると推測される。 しかし，スポーツ選手における自身の体格への関心の強 さや心理的要因が TEI 評価誤差に与える影響については, 今後, さらに検討が必要であろう。

第 4 に, 評価誤差には過小評価と過大評価があるが, 本研究では過大評価した者の人数が少なく, 過小評価に 影響する要因と過大評価に影響する要因の比較はできな かった。

\section{5. 食事調査方法についての課題}

本研究の食事調査では, 秤量法による食事記録法に加 え, 写真撮影および管理栄養士の聞き取りによる食事記 録内容の確認を行った。それにもかかわらず，算出され たTEI には評価誤差が生じ，その個人差は大きかった。 調査には常に誤差が含まれると推測されるが, その誤差 の大きさや誤差の生じる原因を明らかにし，誤差を小さ 
くする努力は必要であると考える。食事調査をより正確 に実施するための記録者側の問題としては，本研究にお いて, 過小評価群の菓子類摂取量および食事回数が, 高 精度群よりも有意に少なかったことから，菓子類を含む 間食をより正確に記録する必要性が考えられる。そのた めに測定者側は，1）対象者に菓子類や間食に記録漏れ が生じやすいことを説明し, 意識して記録するよう依頼 する，2）食事記録内容の確認を, 記録用紙の回収時の みでなく, 食事調査期間中にこまめに実施する， 3 ）菓 子類を摂取した場合には, 写真撮影に加えてラベルや容 器を保管するよう対象者に依頼する，4）移動中などで も記録が容易にできるように記録用紙を改良する，と いった工夫を施す必要があると考えられる。一方, 実際 には菓子類を摂取していたとしても，菓子類を好ましく ない食品と考えて記録されないことや，過小に記録され ることを防ぐためには, 調査結果の使用方法を丁寧に説 明するなど，食事内容を正確に記録することへの不安を， 少しでも除去できるような配慮が必要であろう。

また, 本研究では検討していないが, 評価誤差には調 査者側の影響があることも否定できない。本研究では, 秤量できなかった食品は写真や対象者が記録した目安量 から調査者が重量換算をしており推定誤差が含まれてい るが，本研究結果への影響の大きさは不明である。

\section{V. 結 論}

本研究では, 4 つの競技種目（陸上中長距離, 水泳, 新体操, ラクロス）の女性スポーツ選手を対象とし, 二 重標識水法により測定した総エネルギー消費量を基準に, 食事記録法による総エネルギー摂取量の評価誤差に関連 する要因の検討を行った。その結果, 以下のことが判明 した。

1. 総エネルギー摂取量の評価誤差の平均值は 4 競技 とも負であり, 新体操 $(-42.0 \pm 15.3 \%)$ がラクロ ス $(-2.8 \pm 38.3 \%)$ と比較して有意に過小評価して いた。

2. 過小評価群に比べ, 高精度群は菓子類摂取量, 食 事回数, 炭水化物エネルギー比率が有意に多く, 総 エネルギー消費量と脂質エネルギー比率が有意に少 なかった。

3. 総エネルギー消費量が小さいことは, TEI を高精 度に評価することに独立して関連していた。

今後は，対象とする競技種目の再検討および競技種目 ごとの対象者数の増加をするとともに, 心理的要因や社 会的な要因を含めた視点から評価誤差に関連する要因を
検討する必要があると考えられる。

謝辞

本研究の遂行にあたり，ご協力を頂きました対象者の 皆様, ならびに指導者・保護者の皆様に厚く御礼申し上 げます。また，調査に伴う栄養計算にご協力頂きました 独立行政法人 国立健康 - 栄養研究所 栄養教育研究部に所 属する管理栄養士である坂田晶子氏に，心より感謝の意 を表します。

\section{利益相反}

本研究において，利益相反に相当する事項はない。

\section{文献}

1）厚生労働省策定：日本人の食事摂取基準 [2010年版], p. 43 (2010) 第一出版, 東京

2) Poslusna, K., Ruprich, J., de Vries, J.H.M., et al.: Misreporting of energy and micronutrient intake estimated by food records and 24 hour recalls, control and adjustment methods in practice, Br.J. Nutr., 101 (Suppl 2), S73-S85 (2009)

3) Montoye, H.J., Kemper, H.C.G., Saris, W.H.M., et al.: Measuring Physical Activity and Energy Expenditure, pp. 17-25 (1996) Human Kinetics, Illinois

4）高田和子, 別所京子, 田中茂穂, 他：日本人成人にお ける秤量法によるエネルギー摂取量の推定精度, 栄養学 杂倠誌, 69, 57-66 (2011)

5) Okubo, H., Sasaki, S., Rafamantanantsoa, H.H., et al.: Validation of self-reported energy intake by a self-administered diet history questionnaire using the doubly labeled water method in 140 Japanese adults, Eur. J. Clin. Nutr., 62, 1343-1350 (2007)

6) Hill, R.J., Davies, P.S.W.: The validity of self-reported energy intake as determined using the doubly labeled water technique, Br. J. Nutr., 85, 415-430 (2001)

7) Ebine, N., Rafamantanantsoa, H.H., Nayuki, Y., et al.: Measurement of total energy expenditure by the doubly labeled water method in professional soccer players, $J$. Sports Sci., 20, 391-397 (2002)

8) Ebine, N., Feng, J.Y., Homma, M., et al.: Total energy expenditure of elite synchronized swimmers measured by the doubly labeled water method, Eur. J. Appl. Physiol., 83, 1-6 (2000)

9) Singh, R., Martin, B.R., Hickey, Y., et al.: Comparison of self-reported and measured metabolizable energy intake with total energy expenditure in overweight teens, Am. J. Clin. Nutr., 89, 1744-1750 (2009)

10) Sawaya, A.L., Tuckey, K., Tsay, R., et al.: Evaluation of four methods for determining energy intake in young and older women: comparison with doubly labeled water measurements of total energy expenditure, Am. J. Clin. Nutr., 63, 491-499 (1996) 
11) Scagliusi, F.B., Ferriolli, E., Pfrimer, K., et al.: Characteristics of women who frequently underreport their energy intake: a doubly labelled water study, Eur. J. Clin. Nutr., 63, 1192-1199 (2009)

12) Goris, A.H.C., Westerterp-Plantenga, M.S., Westerterp, K.R.: Undereating and underrecording of habitual food intake in obese men: selective under-reporting of fat intake, Am. J. Clin. Nutr., 71, 130-134 (2000)

13) Sjöberg, A., Slinde, F., Arvidsson, D. et al.: Energy intake in Swedish adolescents: validation of diet history with doubly labeled water, Eur. J. Clin. Nutr., 57, 1643-1652 (2003)

14) Millen, A.E., Tooze, J.A., Subar, A.F., et al.: Differences between food group reports of low-energy reporters and non-low-energy reporters on a food frequency questionnaire, J. Am. Diet. Assoc., 109, 1194-1203 (2009)

15) Bandini, L.G., Cyr, H., Must, A., et al.: Validity of reported energy intake in preadolescent girls, Am. J. Clin. Nutr., 65 (Suppl 4), 1138S-1141S (1997)

16) Barnard, J.A., Tapsell, L.C., Davies, P.S.W., et al.: Relationship of high energy expenditure and variation in dietary intake with reporting accuracy on 7 day food records and diet histories in a group of healthy adult volunteers, Eur. J. Clin. Nutr., 56, 358-367 (2002)

17) Benardot, D.: Advanced sports nutrition, p. 33 (2006) Human Kinetics, Illinois

18) Hill, R.J., Davies, P.S.W.: Energy intake and energy expenditure in elite lightweight female rowers, $\mathrm{Med}$. Sci. Sports Exerc., 34, 1823-1829 (2002)

19) Edwards, J.E., Lindeman, A.K., Mikesky, A.E., et al.: Energy balance in highly trained female endurance runners, Med. Sci. Sports Exerc., 25, 1398-1404 (1993)

20) Weir, J.B.: New methods for calculating metabolic rate with special reference to protein metabolism, J. Physiol., 109, 1-9 (1949)

21) Wolfe, R.R., Chinkes, D.L.: Measurement of total energy expenditure using the doubly labeled water method, Isotope tracers in metabolic research: principles and practice of kinetic analysis, 2nd ed., pp. 177-202 (2005) John Wiley and Sons, New Jersey

22）健康 - 栄養情報研究会編：国民健康 - 栄養の現状一平 成18年厚生労働省 国民健康・栄養調査報告より一, p. 91 （2009）第一出版, 東京

23) Black, A.E., Prentice, A.M., Coward, W.A.: Use of food quotients to predict respiratory quotients for the doublylabelled water method of measuring energy expenditure, Hum. Nutr. Clin. Nutr., 40, 381-391 (1986)

24) Saltzman, E., Roberts, S.B.: The role of energy expenditure in energy regulation: findings from a decade of research, Nutr. Rev., 53, 209-220 (1995)

25) Fudge, B.W., Westerterp, K.R., Kiplamai, F.K., et al.: Evidence of negative energy balance using doubly labelled water in elite Kenyan endurance runners prior to competition, Br. J. Nutr., 95, 59-66 (2006)

26) Westerterp, K.R., Donkers, J.H.H.L.M., Fredrix, E.W.H.M., et al.: Energy intake, physical activity and body weight: a simulation model, Br. J. Nutr., 73, 337-347 (1995)

27) Fogelholm, G.M., Kukkonen-Harjula, T.K., Taipale, S.A., et al.: Resting metabolic rate and energy intake in female gymnasts, figure-skaters and soccer players, Int. J. Sports Med., 16, 551-556 (1995)

28) Scagliusi, F.B., Polacow, V.O., Artioli, G.G., et al.: Selective underreporting of energy intake in women: Magnitude, determinants, and effect of training, J. Am. Diet. Assoc., 103, 1306-1313 (2003)

29）小清水孝子：審美系女子スポーツ選手の減量時の食事 に扔ける問題点，臨床スポーツ医学， 25, 891-896 (2008)

30) Livingstone, M.B.E., Prentice, A.M., Strain, J.J., et al.: Accuracy of weighed dietary records in studies of diet and health, BMJ, 300, 708-712 (1990)

31) Goris, A.H.C., Westerterp, K.R.: Underreporting of habitual food intake is explained by undereating in highly motivated lean women, J. Nutr., 129, 878-882 (1999)

(受付：平成23年 9 月 14 日，受理：平成24年 8 月 23 日) 


\title{
Factors Associated with Reporting Error for Energy Intake Estimated by Food Records in Female Athletes
}

\author{
Asumi Yoshida*1,*2, Kazuko Ishikawa-Takata*2, Kyoko Bessho*2,*3, Motoko Taguchi*4, \\ Wakako Tatsuta*5, Masayuki Totani*6 and Mitsuru Higuchi*4 \\ ${ }^{* 1}$ Graduate School of Sport Sciences, Waseda University \\ ${ }^{*}$ Department of Nutritional Education, National Institute of Health and Nutrition \\ ${ }^{*}$ Faculty of Human Nutrition, Seitoku University \\ ${ }^{*}$ Faculty of Sport Sciences, Waseda University \\ ${ }^{* 5}$ Department of Sports Medicine, Japan Institute of Sports Sciences \\ ${ }^{* 6}$ Graduate School of Human Life Sciences, Showa Women's University
}

\begin{abstract}
Objective: To examine factors associated with reporting error for total energy intake (TEI), which was estimated from food records and by doubly labeled water (DLW) method in female athletes.

Methods: Our study comprised 38 female athletes (middle and long-distance runners, swimmers, rhythmic gymnasts and lacrosse players). Calculated total energy expenditure (cTEE) was calculated from total energy expenditure (TEE), which was assessed by the DLW method and changes in body weight during the study period. TEI was assessed using food weight records from the TEE assessment period.
\end{abstract}

Results: cTEE and TEI were, respectively, 2,673 $\pm 922 \mathrm{kcal} /$ day and 2,151 $\pm 434 \mathrm{kcal} /$ day for runners, $2,923 \pm 749 \mathrm{kcal} /$ day and 2,455 $\pm 297 \mathrm{kcal} /$ day for swimmers, 3,276 $\pm 497 \mathrm{kcal} /$ day and 1,852 \pm 314 $\mathrm{kcal} /$ day for gymnasts, and 2,628 $\pm 701 \mathrm{kcal} /$ day and 2,329 $\pm 407 \mathrm{kcal} /$ day for lacrosse players. Reporting errors were $-13.6 \pm 24.1 \%,-13.3 \pm 14.3 \%,-42.0 \pm 15.3 \%$, and $-2.8 \pm 38.3 \%$ for runners, swimmers, gymnasts, and lacrosse players, respectively. Reporting error was significantly greater in gymnasts than in lacrosse players. However, no sportive attributes in body composition or dietary intake among four groups were observed. Subjects with high precision TEI assessment had lower TEE, a lower proportion of energy intake from fat, higher intake of confectioneries, higher number of meals, and a greater proportion of energy intake from carbohydrates than subjects with under-reporting in TEI assessment. Low TEE was significantly and independently associated with high precision in TEI assessment.

Conclusions: In female athletes, TEI reporting error was related to TEE, type of sporting activity, confectionery and macronutrient intake, and number of meals. Further research is needed to assess psychological and social factors that may contribute to TEI reporting error.

Jpn. J. Nutr. Diet., 70 (5) 305 315 (2012)

Key words: female athletes, doubly labeled water method, food record, underreporting 